\title{
NARRATIVES OF THE INVISIBLE Autobiography, Kinship, and Alterity in Native Amazonia
}

\author{
Vanessa Elisa Grotti and Marc Brightman
}

\begin{abstract}
Shamanic knowledge is based on an ambiguous commensality with invisible others. As a result, shamans oscillate constantly between spheres of intimacy, both visible and invisible. A place of power and transformation, the spirit world is rarely described by native interlocutors in an objective, detached way; rather, they depict it in terms of events and experiences. Instead of examining the formal qualities of accounts of the spirit world through analyses of ritual performance and shamanic quests, we focus on life histories as autobiographical accounts in order to explore what they reveal about the relationship between personal history (and indigenous historicity) and the spirit world. We introduce the term 'double reflexivity' to refer to processes by which narratives about the self are produced through relationships with alterity.
\end{abstract}

Keywords: alterity, autobiography, double reflexivity, kinship, personhood, shamanism, spirit world, Trio

Before I was born, Sirirumai knew that I would be a shaman. 'He will be a shaman,' he said about me to others. 'He is destined to be a shaman, for there are spirits all around him and within him.' He said that before I was born. (Wetaru and Koelewijn 2003: 338)

Native Amazonian societies live and engage with a world in which what is visible is never given, where things and people change form and where appearances are deceiving. Apprehending the invisible-that is, relating to persons who cannot be seen by all-is the skill given to shamans. Shamans have 'sight', the capacity to see what others cannot, and this powerful ability allows them to interact with spirits and develop bonds of commensality with invisible others. This ambiguous commensality places them in a constant oscillation between spheres of intimacy that are both visible and invisible (Chaumeil 1983; Rivière 1994, 1995). The spirit world, a place of power and transformation, is rarely 
described by native interlocutors in a detached, objective way, but rather in terms of experiences and events. ${ }^{1}$ Personal accounts of experiences with the invisible have been studied widely with regard to the shamanic initiation and quest, a genre also familiar to students of shamanic societies outside Amazonia (Chaumeil 1983; Eliade 1964; Harner 1973). In native Amazonia, a genre of ritual autobiography exists that combines mythic narratives and stories of personal experience in performances of dreams and visions, and the analysis of such oral texts, together with studies of native Amazonian mythology, has already given rise to an important body of work (e.g., Basso 1995; Basso and Senft 2009; Course 2009; Déléage 2007; Oakdale 2005, 2009).

Instead of focusing on the formal qualities of personal accounts of the spirit world by analyzing either ritual performance or the genre of shamanic quests, we shall consider life histories as autobiographical accounts, to explore what they reveal about the relationship between history (and indigenous historicity) and the spirit world (cf. Hendricks 1993). In our analysis, we suggest that this is characterized by a form of 'double reflexivity', by which we mean a reflexivity that is both internal to the self and constituted through relationships between interlocutors. Such a concept has a particular poignancy in the context of native Amazonian personhood, which is understood to be malleable and relationally constituted. This notion of 'double reflexivity' is not identical to the concept of 'hyper-reflexivity' introduced by the editors of this issue. The former is grounded in more pervasive aspects of native Amazonian thought and practice, whereas the latter appears as a more global phenomenon with a particular relationship to anthropological discourse. In an Amazonian context, hyperreflexivity can be seen as a particular form of enactment of double reflexivity, although it may be difficult, even impossible, to identify where one ends and the other begins. However, to reduce our argument to this point would not do justice to the richness of the autobiographical material we discuss. We therefore deliberately seek to leave our article partially open-ended, giving scope for the material to speak for itself. In doing so, we attempt to put the ethnographic object on the same footing as the anthropologist's gaze, in keeping with the aims of this special issue as a whole.

The life histories presented in this article were collected among the Trio people in the Surinamese village of Tëpu, in which a number of Wayana and most of the surviving nomadic hunter-gatherer Akuriyo also live today. Like the other main Trio and Wayana villages, Tëpu is an old mission station founded by North American missionaries from the West Indies Mission and the Unevangelized Fields Mission in the second half of the 1960s on the upper reaches of the Tapanahoni River in the district of Sipaliwini, in southern Suriname. Since 2003, we have both worked among these three Central Carib groups, mainly focusing on the Trio. The Trio and Wayana are swidden horticulturalists who, prior to contact and sedentarization, ${ }^{2}$ lived in smaller, semi-nomadic cognatic groups of about 30 people, which usually settled alongside creeks and maintained a powerful ontological engagement with the forest and the river. ${ }^{3}$ Since the 1960 s, they have lived alongside each other in sedentary villages across the triple border that separates Suriname, French Guiana, and Brazil. While their kinship-making 
process through the quotidian conventions of nurture of kin and commensality with affines remains characterized by a strong ideal of endogamy and uxorilocality (Rivière 1969, 1984), and despite their distinct historical backgrounds, Trio and Wayana alike have developed in their individual and collective discourses a new emphasis on a historical shift that they respectively describe as 'pacification' and 'opening up' (Grotti 2009, 2013; cf. Chapuis and Rivière 2003). In these discourses, the Trio and Wayana emphasize the novelty of their pacified, post-contact bodily and communal states, marked by population aggregation in village formations numbering between 100 and 300 people (and up to 1,000 for the Trio village of Kwamalasamutu in southwestern Suriname), situated along large rivers. They contrast this with their past state, characterized by life in the shelter of the forest in small groups in a state of heightened predatory and transformational capacities. As Gabriel, ${ }^{4}$ the Wayana son-in-law of our Trio host, once told us: "Before, people did not have many kin, they lived in little villages, they did not go to the places of other people, they looked after their young daughters, they did not live like in this village here [Tëpu], they lived near the forest, just inside the forest. Then, they saw them [spirits] all the time, because we [the Wayana] could still transform into different beings-this was just before we transformed into real people [true Wayana]."

For the Trio and Wayana, contemporary life is characterized by a shift in the management of alterity, whereby other people-for example, distant affines, other Amerindians, and other types of people such as Maroons (mekoro) ${ }^{5}$ and urban people (pananakiri, or palasisi in Wayana)-have become the privileged location of alterity, previously held by the forest and its spirits (Grotti 2013). ${ }^{6}$ Native descriptions and interpretations of historical change are therefore inseparable from the question of how people relate to the dead and to the spirit world, not to mention the 'new' world 'opened up' by the 'pacification' of sedentary living. ${ }^{7}$ The past actions of kin and the interventions of spirits are also perceived as central elements in the formation of a person, and, as we shall see, they are at center stage in the accounts of individuals' biographies, their iwehtoponpë (lit., 'former way of being'). But first we will briefly discuss the forms and uses of biography in Amazonian ethnology.

\section{Biographies: Mediated Lives or Dialogical Histories?}

In contrast to lowland South America, indigenous autobiography is a highly developed form in North America, but this must be understood in its historical context. Citing Brumble's (1988) study of Native American autobiography, Sáez (2007: 14) writes: "[T]he collection of indigenous autobiographies was a significant part of a civilizing process, a resource for educators, indigenists, and missionaries to obtain 'individual souls' to fit the psychological requirements of the West." " While they clearly engage with the Western individualist tradition, native autobiographies do not simply emerge from it, nor are they simply mediated by outsiders. To say this would be to suggest that beneath the process of mediation (i.e., soliciting, transcribing, organizing, and publishing native 
testimonies) lies an 'authentic' version of the text that the reader glimpses as if through a glass darkly. We would suggest that any kind of text that is produced collaboratively bears the signs of the relationship out of which it grew, even to its core. We argue further that this has a special significance and resonance for the native peoples of Amazonia, for whom the growth and health of the person and the reproduction of society depend upon both predatory and nurturing relationships with alterity. The specific features of native Amazonian personhood (Grotti and Brightman 2012; Miller 2007), composed of multiple relations with alterity, suggest an answer to Sáez's (2007: 15) question: "[W]hat is an indigenous narrator talking about when he talks about himself?" We shall argue that the answer to this question is that he or she is talking about others, yet in ways that inescapably reflect his or her own (often 'original') social perspective.

The emerging genre of native Amazonian autobiography characteristically situates its subject as an Amerindian in relation to non-Amerindians (Sáez 2007). Indeed, biographical texts are most often produced through a dialogue between an Amerindian and a non-Amerindian, whether the latter be an ethnographer, a missionary, or some different kind of other (see Biocca [1969] 1996; ${ }^{9}$ Cognat [1967] 1987, 1977; ${ }^{10}$ Kopenawa and Albert 2012; Rubenstein 2002). This reflects the native perception of the genre as a white or nonAmerindian mode of expression, which frequently finds its way into the texts themselves, and of the production of the text itself as a way of relating to the non-Amerindian other. ${ }^{11}$ This observation illustrates an important way in which the 'ethnographically astute' informant is produced. In fact, such autobiographical texts, despite being ostensibly about their authors and their cultures (Carneiro da Cunha 2009), can simultaneously be regarded as commentaries on the white, urban cultures for whom (or at least in whose formal tradition) they were written (see, e.g., Kopenawa and Albert 2010). When we read native texts that have been solicited and mediated by outsiders, a double reflexivity occurs as we see our own culture reflected back at us. This is perhaps the most common and the oldest form of indigenous testimony. The claims to authenticity made by early European travelers to the New World are based not only on having 'been there', but also on testimonies recorded by the authors. Ralegh's ([1596] 1997: 181) interview with "one old Topiawari, with whom I much desired to have farther conference" provides the source of strategic information for a prospective invasion of Guiana. But in such accounts, even those that seem most faithful to events (e.g., de Léry [1578] 2008; Staden [1557] 2008), the native voice is hidden behind that of the European narrator.

In Amazonia, and particularly in the past decade or so, anthropologists have paid attention to traditional ritual autobiographies and to the self-affirming narratives of indigenous leaders. The autobiographies of leaders discussed by Sáez (2007) represent the use of a genre that focuses on the self to affirm the collectivity. Leaders embody the group, and, as 'magnified persons' (Fausto 2012), they submit a non-native genre to the logic of their role. But a form of indigenous biography that has received scarcely any attention strikes us as having particular importance, especially in the context of emerging indigenous spiritualities through conversion to Christianity. Protestant evangelical missionaries 
have a particular interest in testimonies that is based on a long tradition. ${ }^{12}$ With discernible roots in the biblical parable and, perhaps more directly, in Pauline conversion testimony, the (auto)biography plays a central role in missionary practice. Dowdy's (1963) Christ's Witchdoctor, a sensational account of the conversion of a Waiwai shaman in neighboring Guyana, is a clear example. The author explains that he chose to tell the story of the conversion of the Waiwai "through the experiences of their chief. He and their testimonies to the grace of God are living witness to the dedication and skill of those who brought the news about God to the jungles of British Guiana” (ibid.: ix). This book, a bestseller in evangelical Christian circles, was clearly intended for the home community of the church and donors to the missionary endeavor.

Here we will discuss a very different example of missionary autobiography, which highlights the important role that missionaries have played in introducing literacy, in the form of the Bible, as a source of knowledge and power, and as a practice through the teaching of reading and writing. Tëmeta Inponopihpë Panpira (Tëmeta's Testament) (Wetaru and Koelewijn 2003) appears at first sight to be another evangelical parable-the story of a shaman who gave up his powers to embrace Christianity. In this case, however, the voice is that of the shaman Tëmeta himself, transcribed from a long series of interviews with the former missionary schoolteacher Cees Koelewijn. Tëmeta was not a cosmopolitan leader familiar with world cities and international conferences, like those discussed by Sáez (2007), yet he was known throughout the region as an exceptionally powerful shaman. The production of Tëmeta's 'testament' emerged from a long and affectionate relationship between him and Koelewijn and from their shared interest in spirituality. Koelewijn is an actively practicing Dutch Protestant, but despite his friendly relationship with the American missionaries who are active in Suriname, he does not share their belief in the necessity of radically transforming indigenous culture, of 'wiping the slate clean' to start anew. Instead, his long experience among the Trio, and especially his friendship with Tëmeta, nurtured in him a great affection for Trio culture, which he saw as containing glimmers of revelation, expressed in certain Trio myths. Koelewijn's mastery of the Trio language and his fascination with the invisible world of spirits and shamanism equipped him, perhaps uniquely, to mediate between these two worlds and, indeed, between these two autobiographical genres, the missionary and the anthropological.

Tëmeta's autobiography was published in a dual Trio and Dutch-language edition in 2003, a few years after Tëmeta's death. Its intended readership is not a home community of churchgoers and mission donors; instead, it is primarily conceived as a gift to the Trio themselves. Koelewijn played an important role in introducing literacy to the generation of young Trio who attended his school in the 1970s. He organized a party in Tëpu to formally present the book to the village, whose leader (kapitein) is one of Tëmeta's sons, and to open the small library that Koelewijn had built to house a collection of books related to the Trio, including his own transcriptions and translations of Trio myths (Koelewijn 1984; Koelewijn and Rivière 1987). In this case, the motivation for producing and, indeed, giving the book to the Trio people appears complex. Partly, it may 
be to encourage others to give up the 'old ways' of shamanism and embrace Christianity as Tëmeta did. However, Koelewijn writes in the Dutch version of the foreword that the book is a studiebook of information on Trio culture, and it is in fact a rich, complex testimony. Far from portraying the 'old ways' as uniquely evil and reprehensible, it offers them from a human perspective in all their beauty and tragedy.

\section{Mapping the Past: Dead Relatives and Abandoned Villages}

It is worth underlining that Tëmeta's autobiography is an exceptional text. Among Trio people, its author (who was crippled by polio) had an extraordinary ability as a storyteller. His knowledge of the spirit world was unmatched, and his family history was unique, as we shall see. Compared to other cases across Amazonia, Tëmeta's account stands out for its aesthetic and emotional qualities, even alongside those of other astute, politically self-aware subjects, who tend (like him) to be leaders or shamans. Everyday experience is sometimes left out of the accounts of such individuals, as Oakdale (2009) discovered when she solicited a life history from a powerful shaman. When he finally agreed to her requests, "[r]ather than the comprehensive life history I had been expecting, [the shaman Prepori] narrated an account only of how he had developed his shamanic skills" (ibid.: 164). We did not find quite such a marked contrast between ordinary and powerful informants among the Trio. It is possible that this difference arose in part from the intimate circumstances of the documentation of the shaman's story. Be this as it may, even the story of Tëmeta's initiation is unique in many ways.

We collected life histories from charismatic, respected senior figures accustomed to speaking to an audience and from more modest individuals without any pretensions to privileged experience. In each case, we asked our interlocutor to tell us his story, ${ }^{13}$ to speak to us about his past, his iwehtoponpë, or 'former way of being'. Like Tëmeta's testimony, the former shamans who told us their stories gave us more than an account of their shamanic initiations, and all of our interlocutors gave us personal accounts without any features of ritual performance. Boaz, our host grandfather in Tëpu, related the following: “Today, Vanessa is here in Tëpu. She has come here. I have also come here from my own village. I was little in Pono Eku, which was a very large village; there were many of us there ... Now I live in Suriname, in the white people's village [pananakiri ipata]." Here Boaz illustrates a tendency shared with all of the people whose life stories we collected. They describe one or, more often, several places in which they spent their childhood and youth and mention their close kin with whom they lived in those places. Most narratives read almost like lists of people and places. By way of example, here is an extract from Tim's story:

We were there before, at Pokorowa. I was at Tëpumïn Eneto, and I was in that village. I was small there, and my father was there, he had married my mother. My father went to Paruma, he had lived in Paruma. So there, in Pokorowa, my 
father married my mother. So they had children, me and my brothers. I was born in Tëpumïn Eneto. But my grandfather did not want my mother to marry my father, because he was not kind to other people. But Tamarema was very kind, he was the father of my uncles. Tamarema was also the father of my mother. My mother was there in Tëpumin Eneto, there were Kuramenaru and Jukëreton, their father was kind and happy ... Then, we left the village of Pokorowa because somebody died there, it was my aunt who died. Then we went to the new village of Oto Entu. I was there because my father had made a new village. Then my father died in Tïpokïnen Kentë ... Two people died in our old village of Oto Entu. Then we went to the other village of Susare Eku ... then my uncle died, my mother's brother. Then we went a bit further down, to Siririkane, near Surare Eku, we used to say that the Siririkane was a water spirit ... then we left because we no longer had a leader. That's why we split, we separated. First we were with our relatives in Kuwatapenman. Sïkrai died in Kuwatapenman, he lived in Tinkaipoeinkato ...

The story continues with several more deaths and migrations, until the Americans appear and preach the gospel, and Tim and his family come to settle in Tëpu:

I still wanted to go back to my place. But we had come from Paru and we wanted to stay here in Tëpu ... We have lived here since $1962 .{ }^{14}$ But I do not know how long it had been since we were in Paruma, I do not know because then I could not read and count the calendar. Here in Tëpu, I learned to read the years of the calendar ... so now there are calendars. Today we are in the month of May, we also know the days, because there are calendars, and we also know how to read the years. Now we remember everything.

The places and people of the speaker's youth represent a finished past that lacks continuity with the present. When Tim and others come to mention Tëpu, 'the white people's village', they appear to evoke another, more recent era-the present-and another time, one measured with clocks and calendars (Brightman 2012). In doing so, Trio narrators emphasize a rupture with a past that is associated with an isolated life in the forest and regular migrations through a landscape made of places created and abandoned to the spirits at the death of their founder (cf. Robbins 2007; Vilaça and Wright 2009). The present is a life of increased physical interaction with former enemies and distant affines alike, in permanent villages that have survived the death of their foreign, missionary founders. Rather than being abandoned, houses remain occupied by widows and grandchildren following the death of one of their occupants, and bodies of the dead are buried in a cemetery.

Most Trio people evoke the spirit world directly only when they mention the deaths of their kin, as this extract from Julius's story illustrates: “There. That's how it was. So I didn't have any more sisters. My father died because of ëremi [spirit curses]. My sister died because of curses. My uncle died because of curses, that's all. The Trio were terrible poisoners. They used to take the earth you walked on. They took the seeds of sweet peas, that's the fruit ... they also scraped the paint from the skin, or they would cut our hair while we slept. 
That's what the Trio used to do, they were terrible poisoners." These narratives focus on dead relatives and abandoned villages-people and places that return to alterity. They evoke encounters and events centered on social life in the village: initiation, growing as taught by parents, marriages and children, migrations between settlements, and death from witchcraft. Conversion comes as a point marked by the arrival of white people who, in the Trio's words, start to teach and 'grow' (arimika) them. Trio narrators struggle to reproduce concepts introduced through the conversion process. They often return to the missionary idea of spirits being 'bad', but they seem frustrated that neither spirits nor Jesus can be seen. Jesus, they are told, is a spirit (omore) who lives in the sky.

This emphasis on historical rupture is present in both Trio and Wayana discourse. Among the Trio, the state of 'pacification' (sasame wehto) becomes entangled with the arrival of the missionaries in Suriname, an event that did not occur among the Wayana who live in French Guiana and instead underwent a 'secular' process of sedentarization. The missionaries' intense interest and scrutiny of the invisible world, considered as the satanic source of the evils of indigenous Amazonian societies, is reflected in Trio life narratives, which all dwell on the missionaries' repeated questions and discourses on all matters mystical - a feature that, to our knowledge, is not found in French Guianan Wayana narratives. Conversion, 'trying God' (i.e., praying), and listening to missionaries' ideas are reproduced in most Trio life stories, and these elements take a dramatic turn in narratives of shamanic conversion, as in Tëmeta's case. Conversion was visually (and dramatically) represented in the action taken by shamans like Tëmeta when they destroyed their shamanic rattles containing their spirit familiars. ${ }^{15}$

Thus, with an ironic twist of circumstances, indigenous life histories that were 'informed' by missionary literary practices tend to spontaneously dedicate greater space to the invisible world, as opposed to those practices informed by a secular process. In this context, the life narratives of Trio shamans become rich narratives of encounters and travels to the invisible world, as if to provide a dramatic contrast to the conversion to Christianity whose description they anticipate.

\section{Alterity Within: Encounters and Sociability in the Invisible}

Even when they speak of their kin in the past, the Trio evoke another worldthe world of the dead. But if ordinary accounts of the making of a life describe relatives in far-off times and places, kinship is further twisted and inverted in the case of the shaman, and alterity is explicit, a counterpoint to the image of incest. Tëmeta was haunted by the idea that he was the product of an incestuous relationship between his brother and his mother: "So that's how it was when I was small. That's why I'm here now. I had no father, and the others, well ... My brother said that he did have a father. 'Apatu is my father', he said, 'the father of Poje. I'm your father,' he told me ... So, as a child I lived with the man who saved me, with Sirirumai. He brought me up. I lived with him and 
my mother then lived with him too as his wife. I remember the time when my family didn't love me. Neither my sister nor my brother loved me. So I went to live with others and to grow up with them" (Wetaru and Koelewijn 2003: 340). Because of the alleged incestuous relationship between his mother and brother, Tëmeta became estranged from his kin. His adoptive father, Sirirumai, was a shaman. It was from this point on that Tëmeta began to discover that his kin were spirits: "Sirirumai was a pijai [a shaman]. Sirirumai had said that I was also the son of an irïpï [spirit]. 'Whose [from whom] is he anyway?' he had asked. 'He is definitely the son of an irïpï. Maybe he is indeed a Trio, but I always see an atmosphere of spirits around him.' That's what Sirirumai had said to others before he died" (ibid.: 341).

Kinship is at the heart of the relationship between the shaman and his familiar spirits. Both shamans and spirits have ikopija, or spirit helpers. Shamans keep material manifestations of their spirit helpers, kuri, in their rattles, and they feed them with tobacco smoke and address them as their children. Yet it is clear from Tëmeta's account that it is the spirits who solicit him (Wetaru and Koelewijn 2003: 341):

One day the spirit began to make me into a shaman. I did not begin to be a shaman by myself. I made no effort of my own. I was quiet, I held still. I did not know what it meant to be a shaman. That's how it usually happens, we do not know exactly how it is when we are shamans. Who can know that he is a shaman as a child? That's how it also was with me, I did not know. It was exactly as though I were lifted up. How shall I say ... dizzy, yes, I felt dizzy. I fell on the ground and then a spirit came to me. Maybe the spirit threw me on the ground in order to have a good look at me. Seeing a spirit makes you dizzy. That's how it was with me. It made me dizzy so that it could look ... Then I really saw him, then maybe the spirit was with[in] me ... What do spirits actually do with you? A spirit that dwells within us possesses something. "You are like our stuff, our material," said the spirit to me, "that's why we come into you and then we help you." That's how it was. The spirit then came into me. I became its possession. It happened quite naturally. It overcame me. I did nothing to become a shaman.

It is striking that here, as he becomes a shaman, Tëmeta is called, initiated, and 'possessed' by the spirit. The spirit is his master. This inverts the more common notion that the spirit familiars of a mature shaman are his possessions, his pets, his children (Chaumeil 1983; Fausto 1999; Miller 2007).

As we mention above, Trio shamans referred to their spirit familiars as their children, and when they converted to Christianity, they agreed to destroy the rattles in which these familiars were contained. Peter Rivière, who carried out field research among the Trio in the early 1960s, witnessed some of these events and even played a role by agreeing to take some rattles with him to England when he finally left the field. The three Trio shaman's rattles that Rivière took were considered as good as destroyed. Rivière donated them to the Pitt Rivers Museum in Oxford, and in his written comments on these objects, ${ }^{16}$ he includes a quotation from Tëmeta's autobiography, which describes the pain Tëmeta felt at having to destroy his child: 
At this point my rattle became distasteful to me, I did not want it, I looked on it as if it were a toy. God did this to me. Then I no longer had trust in it, I did not believe in it. I said to the missionary [Morgan Jones], "Perhaps it is rubbish." I said, "What shall I do with it, where will I put my rattle? Shall I just pour out its contents, shall I just throw them away?" However I did not want to throw them away myself. I proposed to Morgan that he should destroy them if he wanted to. He answered, "You had better destroy them." "I do not want to do that because they are like children to me. So you may do it if you like, just destroy it” I said. "Who in the world destroys something that is like a child to him. Maybe someone else can destroy my child. So I want you to do it," I said to him. "Yes, that is all right," he said and then he poured them out and threw them into the river. (Wetaru and Koelewijn 2003: 357; trans. P. Rivière)

What these two passages show is that spirits may be both masters and pets/ children of humans at different times: Tëmeta is solicited by spirits as a child, but later becomes their master. The theme of mastery has become a significant one in Amazonian ethnology, as the importance of ownership and nurture as structuring principles in native Amazonian relations in the areas of politics, cosmology, ecology, and kinship is becoming increasingly clear (Brightman et al., forthcoming; Fausto 2012). Bonilla (2005, 2007, forthcoming) has shown that the position of prey, pet, or client may be actively sought and desired, and that submission can be part of a 'parasitic' strategy of life. Tëmeta's case further illustrates that the relationship between master and pet can also be inverted during different stages of life.

\section{Souls and Spirits}

We can now turn to the nature of the invisible world, populated by souls and spirits. The most commonly mentioned type of Trio soul, omore, is the image soul' or 'eye soul', which is also equated with the 'shadow'. There are other kinds of soul, less consistently mentioned by the Trio, that live in other parts of the body. These aspects of soul or soul matter seem to reside where there is a pulse, such as in the wrists and neck, below the knees, and in the heart. This is why the Trio adorn these parts of the body with bead ornaments. They are especially placed on children since their souls are not yet considered to be firmly attached to their bodies, making them more vulnerable to spirit attack.

Along with body and soul, there is a further constituent element of the person for the Trio-a person's name, or $e k a$, which has been interpreted as performing the role of binding the body and soul together (Rivière 1999). The name persists after death, although it is not uttered for a period until the body and soul are fully separated and the corporeal elements of the individual person have been forgotten. At this point, the name of a deceased person, often a grandparent, can be given to a baby. Names seem to be elements or emanations of the self, and the living cannot share names. Moreover, each individual has several names, at least one of which is never uttered. The others are 'public' names that have less powerful associations with the soul. 
Souls are not the only invisible entities in the Trio's universe. There are also

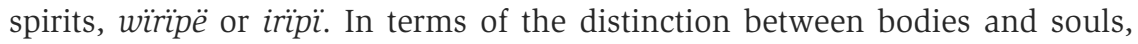
spirits seem to be invisible bodies-only shamans can see them, and they see them as persons with bodies of human or animal form. ${ }^{17}$ Here Tëmeta is describing his experience as he was being turned into a shaman: "Then the real spirit changed me. It wanted to make my body the same as that of its own. I saw all kinds of figures. They looked like people [wïtoto], like Maroons, like animals ... I saw the transformations of animals, I saw the metamorphosis of anteaters. So I saw all that, animals and spirits that changed into people" (Wetaru and Koelewijn 2003: 342-343). Spirits are not only or always invisible to all but shamans, however. Levi, a former shaman who became a prominent church pastor, told us about some of the animals, especially birds, that are, at least in some cases, spirits: “Our grandfather told us ... 'the eagle, it's a spirit [wïripë]'. The eagle had a costume, it's a spirit. The eagle is like the costume of a spirit." Certain bird-spirits are also helpers or advisers in specific situations or are associated with specific animals. Certain animals-snakes, jaguars, eagles, rats-must not be touched or eaten because they are spirits.

Shamans and spirits are characterized by their ability to metamorphose by putting on the 'clothes' of other beings. This happened to Tëmeta even before he was born when a spirit came to inhabit his body. His mother thought her unborn baby was dying because when she went into the water to bathe, she could no longer feel it move. The water is also the spirit realm, and a shaman told her, "He is not dead. He is just keeping still. It is as if he is unconscious because there is an irïpi in him. The spirits have made him still. He will later be a shaman" (Wetaru and Koelewijn 2003: 341). As a child, Tëmeta grew ill with polio, and he thought that he was being attacked by spirits. But his shaman uncle and adoptive father told him that it was 'other people' who were sending spirits against him. As we have seen, he had said that Tëmeta had had spirits all around him, since his birth, and that these spirits wanted to help him. At this point, as he was struggling with his polio, Tëmeta came to know the spirits and to become a shaman. His uncle gave him a medicinal bath, and suddenly he was able to see clearly: "After the bath everything was clear to me, just as the shaman had predicted. The spirit came near me and spoke with me, he told me about everything, he was my kin [jimoitümeken] ... If I went on a journey, in the air or on the ground, I had a solid path, my path was good. I learned how a spirit travels, I learned how spirits are ... I could see the spirits, and where they were and also what they did, which spirits were false and dangerous and which went hunting for victims" (ibid.: 344). At this point, Tëmeta is able to put on the 'clothes' of the spirits: "I was in him, I was in the wïrïpë, I wore his clothes [ipotao]. That’s how we call it: we wear their clothes. That's what I did. So the irïp $\ddot{~ m a d e ~ m e ~ l i k e ~ i t s e l f: ~ s e l f-a s s u r e d ~ a n d ~ i n v i n c i b l e ” ~}$ (ibid.: 345). So there are clear relations of kinship and even evocations of the life-course between shamans and their spirits. Tëmeta was the son of a spirit; when he became a shaman, he became the kin of the spirits that had been around him from birth. And he soon came to have his own spirit children, whom he nurtured and fed. ${ }^{18}$ 
The relationship between souls (omore) and spirits (wïrïpë) suggests that spirits are very much like bodies. The person is a combination of body and soul, sealed with a name, but the shaman is able to transform his bodily envelope into that of another species, and even into that of a spirit, without completely losing his original social perspective. However, Levi told us that the missionaries challenged these beliefs by preaching that the soul does not die. If a person has 'tried Jesus', then his soul goes to the sky (kapu); if he is sinful (wïrïpëme), or does not try Jesus, then it goes to the great fire, that is, seitan, or hell. Another informant, our host grandfather Boaz, told us that those who died before the arrival of the missionaries also went to seitan, but the difference between this description of hell and the traditional notion of omorenpë pata, the place of the dead souls, is not clear. This place traditionally had no moral accent, whereas hell clearly does. The missionaries have done their best to equate the two, but their success seems to be only partial. As Mazard also shows in this issue, following the introduction of Christianity, the imposition of dualisms such as body and soul and the equation of spirits with evil and hell meet a peculiar sort of resistance on the part of animist cosmology, which diffuses and refracts such novelties rather than meeting them headlong.

\section{Conclusion}

Personal histories necessarily evoke the dead, and this does not come easily to Trio people. Like other Amazonians, they try hard to forget their dead kin (Taylor 1993), whose physical and spiritual disintegration is such that they are no longer human and their names and other souls are no longer one with their bodies (Vilaça 2000; cf. Mazard, this issue). As among the Javari in Taylor's (1993) account, it may be that forgetting is-or was-necessary to free Trio names and souls so that they might again circulate among the living and become attached to new, living bodies. The decision of the Trio to 'open up', to agree to live in white people's villages alongside affines, and to embrace Christianity signified the possibility of engaging with alterity without fear of reprisals. New names now circulate, as names from the city, from popular media, and from the Netherlands are given to children. This helps to explain why Trio people now have many kin and children and, like other Amazonian peoples, have undergone a rapid population growth in recent decades.

This proliferation of names, an illustration of a wider proliferation of relations with alterity, may well be related to the intense indigenous Christian activity that manifests itself most clearly in large 'Bible conferences' organized each year by Amerindians in different locations across the Guiana region. This can be read as one example of the tendency (transposed to Christianity) for shamanic activity to intensify in situations of contact, as several authors have noted (e.g., Butt 1960; Carneiro da Cunha 1998). This intensification has a corollary in life histories: missionary interest in the spirit world encourages former shamans to give precise descriptions of that world in their accounts. The shaman describes his relationships with invisible spirit others, producing a text in the medium of 
the white other as he speaks about the past, his former self, and his relations with dead kin. He is simultaneously here and elsewhere, a shaman and a pastor, white and Amerindian. Double (or even hyper-) reflexivity are in this way a source of shamanic power. As Carneiro da Cunha (1998) points out, the shaman is able to hold simultaneously several points of view and to translate harmoniously between them. We are reminded of the art of the storyteller, who is able to enchant his listeners and make them enter another world. Autobiographical storytelling emerges among the Trio as part of their 'becoming white' (Kelly 2005) and 'becoming Christian', but the form and content of these stories are also part of a structural relationship with alterity that transcends the rupture of conversion. (Auto)biography shows how people can turn from pets into masters and how they engage with the dead. It shows how Amerindians can become white, if only to remain more conscious of themselves (cf. Sahlins 2005), and it enables converted Christians to talk about their relationships with forest spirits.

No biography comes into existence without a reader, and even autobiography is produced through relationships with others. Animist or perspectivist ontologies may hold more clues for the interpretation of the infinite 'mirroring' of difference that may occur in such instances (Viveiros de Castro 2004). In the case of native Amazonians, life writing constitutes a relationship with alterity of the kind that is necessary for the processual production of the person. Beyond this, and more generally, the (auto)biographical text itself reflects on its subject (author), his or her interlocutor, and their respective social origins and cultural contexts (the differences between which may of course be blurred). In short, it is an artifact of a kind of double reflection that continues to reverberate with every reader.

\section{Acknowledgments}

We are grateful to the editors for their invitation to contribute to this special issue. Some of the initial ideas on which this article is based were presented in a short paper, "Relatives and the Invisible: Kinship, Spirits and the Dead in an Amazonian Society," at a workshop entitled "Ghosts and Apparitions in the Field," convened by Olga Ulturgasheva and Shane McCorristine at the Scott Polar Research Institute, University of Cambridge, on 27 May 2011. We carried out our research thanks to funding from the ESRC, the Gates Cambridge Trust, Trinity College Cambridge, the British Academy, and the Wellcome Trust. Last but not least, we would like to thank our Trio and Wayana hosts for taking good care of us and sharing the stories of their lives. 
Vanessa Elisa Grotti is a part-time Professor at the Robert Schuman Centre for Advanced Studies, where she is leading research funded by an ERC Starting Grant entitled "Intimate Encounters in EU Borderlands: Migrant Maternity, Sovereignty and the Politics of Care on Europe's Peripheries" (ERC-2014-STG, 20152020). A social and medical anthropologist, she is interested in the study of kinship, personhood, and reproduction, especially in contexts of social change and crisis. Her publications include Animism in Rainforest and Tundra (2012, with Marc Brightman and Olga Ulturgasheva) and two forthcoming volumes, Ownership and Nurture: Studies in Native Amazonian Property Relations (with Carlos Fausto and Marc Brightman) and Living with the Enemy: First Contacts and the Making of Christian Bodies in Amazonia.

Marc Brightman is a Lecturer in Social Anthropology and co-director of CAOS, the Centre for the Anthropology of Sustainability, at University College, London. His research interests range from native Amazonian leadership to global political ecology and forest governance. His publications include Animism in Rainforest and Tundra (2012, with Vanessa Grotti and Olga Ulturgasheva) and two forthcoming volumes, Ownership and Nurture: Studies in Native Amazonian Property Relations (with Carlos Fausto and Vanessa Grotti), and The Imbalance of Power: Leadership, Masculinity and Wealth in Amazonia.

\section{Notes}

1. On the theme of transformation, see also the articles in this issue by Diana Espírito Santo and Mireille Mazard.

2. We use the term 'sedentarization' to refer to the transition from a nomadic or seminomadic life in the forest to the establishment of long-term villages that survive the death of the founder or its elders. Although the Trio, the Wayana, and huntergatherer people proper, such as the Akuriyo, remain mobile and travel through the forest and, in the case of the Trio and Wayana, to distant places such as the city and Maroon villages, they now live alongside their dead, who are buried in a cemetery on the outskirts of the village. Sedentarization in this sense means a new relational pattern with the spirit world and the dead. We also aim to remain close to the Trio's description of their present village life and their own bodies as being different from the past and marked by stabilization.

3. The Akuriyo are a hunter-gatherer group who became captive slaves of the Trio following missionary contact expeditions in the 1960s and 1970s (Grotti and Brightman 2010).

4. The names of our main informants are pseudonyms.

5. All words in italics are Trio unless stated otherwise.

6. The management of alterity is a classic theme in Amazonian ethnology (Fausto 1999). For further discussion of the ways in which Trio people 'manage' alterity, see Brightman (2011), Grotti (2013), and Grotti and Brightman (2010, 2012).

7. To the Trio, humanity emerges in the mythic past through separation from the spirit world and the loss of certain capacities. This transformational story of the origin 
of humanity exists alongside the Christian creation story, which Trio people accept as having been told to them by the 'Americans' (missionaries). This may seem paradoxical, even contradictory, unless one considers that each of these cosmologies has its own distinctive spatial and temporal dimensions. Christian stories are associated with a separate, distant past and with faraway places. The space-time of the spirit world, however, is at once distant and ever-present.

8. Unless otherwise indicated, all translations of cited texts are our own.

9. As described by Biocca ([1969] 1996), the case of Helena Valero raises intriguing questions about the relationship between native and outsider in the production of biography in relation to the question of the 'ethnographically astute' informant. A white girl captured as a child by Yanomami people, Helena met Biocca by chance during his expedition in Yanomami territory, and he took the opportunity to record her life history. She was able to communicate a white person's perspective on her experiences because of her background, but having 'become' Yanomami, she chose to remain among them. This case challenges the notion of an 'authentic' native account.

10. Known as Antecume in Wayana, André Cognat ([1967] 1987, 1977) raises another interesting parallel with Helena Valero (see above). Cognat was born in metropolitan France and was adopted into a Wayana household as a young man when traveling in southern French Guiana. He has been living among the Wayana since the early 1960s and is now a village leader and elder.

11. In contrast to some other native Amazonian peoples, the Trio do not have a traditional genre of ritual autobiography.

12. On other dimensions of the widespread influence of this tradition, see Robbins (2004) on confessional narratives and Keane's (1997) discussion of language and agency in a context of Dutch missionization.

13. Women were more reluctant to allow us to record their life stories. One woman, Boaz's sister, did agree. Her story remains typical in emphasizing former places and kin, as discussed below.

14. This date is no doubt a mistake as Tëpu was not founded until a few years later.

15. The relational nature of conversion processes is a feature common to Trio and other native Amazonian experiences and transformations of Christianity. These are discussed at length by Grotti (2009) for the Trio. For comparable cases across the region and a general discussion, see Vilaça and Wright (2009).

16. See http://objects.prm.ox.ac.uk/pages/PRMUID23040.html.

17. On spirits as bodies and the non-dualism of spirits and bodies, cf. Mazard (this issue), Miller (2007), and Vilaça (2005). On the necessity of the relationship with alterity for the production of the person, cf. Espírito Santo (this issue). On the converse case of unfolding the elements of the dividual and projecting partible aspects of the self into the future, see Olga Ulturgasheva (this issue).

18. Also note that, as in Espírito Santo's article (this issue), the spirits act, by turns, as masters, guides, and helpers, occupying multiple shifting roles.

\section{References}

Basso, Ellen B. 1995. The Last Cannibals: A South American Oral History. Austin: University of Texas Press.

Basso, Ellen B., and Gunter Senft. 2009. “Introduction.” Pp. 1-20 in Senft and Basso 2009. 
Biocca, Ettore. [1969] 1996. Yanoáma: The Story of Helena Valero, a Girl Kidnapped by Amazonian Indians. Trans. Dennis Rhodes. New York: Kodansha.

Bonilla, Oiara. 2005. "O bom patrão e o inimigo voraz: Predação e comércio na cosmologia Paumari.” Mana 11, no. 1: 41-66.

Bonilla, Oiara. 2007. "Des proies si désirables: Soumission et prédation pour les Paumari d’Amazonie brésilienne.” PhD diss., École des Hautes Études en Sciences Sociales, Paris.

Bonilla, Oiara. Forthcoming. "Parasitism and Subjection: Modes of Paumari Predation." In Brightman et al., forthcoming.

Brightman, Marc. 2011 “Archetypal Agents of Affinity: 'Sacred' Musical Instruments in the Guianas?” Pp. 201-218 in Burst of Breath: Indigenous Ritual Wind Instruments in Lowland South America, ed. Jonathan D. Hill and Jean-Pierre Chaumeil. Lincoln: University of Nebraska Press.

Brightman, Marc. 2012. "Maps and Clocks in Amazonia: The Things of Conversion and Conservation." Journal of the Royal Anthropological Institute 18, no. 3: 554-571.

Brightman, Marc, Carlos Fausto, and Vanessa E. Grotti, eds. Forthcoming. Ownership and Nurture: Studies in Native Amazonian Property Relations. New York: Berghahn Books.

Brightman, Marc, Vanessa E. Grotti, and Olga Ulturgasheva, ed. 2012. Animism in Rainforest and Tundra: Personhood, Animals, Plants and Things in Contemporary Amazonia and Siberia. New York: Berghahn Books.

Brumble, H. David, III. 1988. American Indian Autobiography. Berkeley: University of California Press.

Butt, Audrey. 1960. "The Birth of a Religion.” Journal of the Royal Anthropological Institute 90, no. 1: 66-106.

Carneiro da Cunha, Manuela. 1998. "Pontos de vista sobre a floresta amazônica: Xamanismo e tradução." Mana 4, no. 1: 7-22.

Carneiro da Cunha, Manuela. 2009. "Culture" and Culture: Traditional Knowledge and Intellectual Rights. Chicago: Prickly Paradigm Press.

Chapuis, Jean, and Hervé Rivière, eds. 2003. Wayana eitoponpë: (Une) histoire (orale) des Indiens Wayana. Matoury: Ibis Rouge.

Chaumeil, Jean-Pierre. 1983. Voir, savoir, pouvoir: Le chamanisme chez les Yagua du Nord-Est péruvien. Paris: École des Hautes Études en Sciences Sociales.

Cognat, André. [1967] 1987. J'ai choisi d'être indien. Paris: L’Harmattan.

Cognat, André. 1977. Antécume ou une autre vie. Ed. Claude Massot. Paris: R. Laffont.

Course, Magnus. 2009. "Why Mapuche Sing.” Journal of the Royal Anthropological Institute 15, no. 2: 295-313.

Déléage, Pierre. 2007. "A Yaminahua Autobiographical Song: Caqui Caqui." Tipití 5, no. 1: 79-95.

de Léry, Jean. [1578] 2008. Histoire d'un voyage faict en la terre du Brésil, ed. Frank Lestringant. Paris: Librairie Générale Française.

Dowdy, Homer E. 1963. Christ's Witchdoctor: From Savage Sorcerer to Jungle Missionary. New York: Harper \& Row.

Eliade, Mircea. 1964. Shamanism: Archaic Techniques of Ecstasy. Princeton, NJ: Princeton University Press.

Fausto, Carlos. 1999. "Of Enemies and Pets: Warfare and Shamanism in Amazonia." American Ethnologist 26, no. 4: 933-956.

Fausto, Carlos. 2012. "Too Many Owners: Mastery and Ownership in Amazonia.” Pp. 29-47 in Brightman et al. 2012.

Grotti, Vanessa E. 2009. "Protestant Evangelism and the Transformability of Amerindian Bodies in Northeastern Amazonia.” Pp. 109-125 in Vilaça and Wright 2009. 
Grotti, Vanessa E. 2013. "The Wealth of the Body: Trade Relations, Objects and Personhood in Northeastern Amazonia." Journal of Latin American and Caribbean Anthropology 18, no. 1: 14-30.

Grotti, Vanessa E., and Marc Brightman. 2010. "The Other's Other: Nurturing the Bodies of 'Wild' People among the Trio of Southern Suriname." Etnofoor 22, no. 2: 51-70.

Grotti, Vanessa E., and Marc Brightman. 2012. "Humanity, Personhood and Transformability in Northern Amazonia." Pp. 162-174 in Brightman et al. 2012.

Harner, Michael, ed. 1973. Hallucinogens and Shamanism. Oxford: Oxford University Press.

Hendricks, Janet W. 1993. To Drink of Death: The Narrative of a Shuar Warrior. Tucson: University of Arizona Press.

Keane, Webb. 1997. "From Fetishism to Sincerity: On Agency, the Speaking Subject, and Their Historicity in the Context of Religious Conversion." Comparative Studies in Society and History 39, no. 4: 674-693.

Kelly, José Antonio. 2005. "Notas para uma teoria do 'virar branco.” Mana 11, no. 1: 201-234.

Koelewijn, Cees. 1984. Tarëno tamu inponopï panpira [Stories of Trio Elders]. 2 vols. Leusden: Algemeen Diakonaal Bureau.

Koelewijn, Cees, and Peter Rivière. 1987. Oral Literature of the Trio Indians of Surinam. Dordrecht: Foris.

Kopenawa, Davi, and Bruce Albert. 2010. La chute du ciel: Paroles d'un chaman Yanomami. Paris: Plon.

Miller, Joana. 2007. “As coisas: Os enfeites corporais e a noção de pessoa entre os Mamaindê (Nambiquara).” PhD diss., Universidade Federal do Rio de Janeiro.

Oakdale, Suzanne. 2005. I Foresee My Life: The Ritual Performance of Autobiography in an Amazonian Community. Lincoln: University of Nebraska Press.

Oakdale, Suzanne. 2009. "Ritual and the Circulation of Experience: Negotiating Community in the Twentieth-Century Amazon.” Pp. 153-170 in Senft and Basso 2009.

Ralegh, Walter. [1596] 1997. The Discoverie of the Large, Rich and Bewtiful Empyre of Guiana. Transcr., annot., and intro. by Neil L. Whitehead. Manchester: Manchester University Press.

Rivière, Peter. 1969. Marriage among the Trio: A Principle of Social Organization. Oxford: Oxford University Press.

Rivière, Peter. 1984. Individual and Society in Guiana: A Comparative Study of Amerindian Social Organisation. Cambridge: Cambridge University Press.

Rivière, Peter. 1994. "WYSINWYG in Amazonia." Journal of the Anthropological Society of Oxford 25, no. 3: 255-262.

Rivière, Peter. 1995. “Ambiguous Environments.” Pp. 39-50 in Threatened Peoples and Environments in the Americas, ed. Magnus Mörner and Mona Rosendahl. Stockholm: Institute of Latin American Studies, University of Stockholm.

Rivière, Peter. 1999. "Shamanism and the Unconfined Soul." Pp. 70-88 in From Soul to Self, ed. M. James C. Crabbe. London: Routledge.

Robbins, Joel. 2004. Becoming Sinners: Christianity and Moral Torment in a Papua New Guinea Society. Berkeley: University of California Press.

Robbins, Joel. 2007. "Continuity Thinking and the Problem of Christian Culture: Belief, Time, and the Anthropology of Christianity." Current Anthropology 48, no. 1: 5-38.

Rubenstein, Steven L. 2002. Alejandro Tsakimp: A Shuar Healer in the Margins of History. Lincoln: University of Nebraska Press.

Sáez, Oscar Calavia. 2007. “Autobiografia e Liderança Indígena do Brasil.” Tellus 12: 11-32.

Sahlins, Marshall. 2005. "On the Anthropology of Modernity; or, Some Triumphs of Culture over Despondency Theory.” Pp. 44-61 in Culture and Sustainable 
Development in the Pacific, ed. Antony Hooper. Canberra: Asia Pacific Press, Australian National University.

Senft, Gunter, and Ellen B. Basso, eds. 2009. Ritual Communication. Oxford: Berg.

Staden, Hans. [1557] 2008. Hans Staden's True History: An Account of Cannibal Captivity in Brazil. Ed. and trans. Neil L. Whitehead and Michael Harbsmeier. Durham, NC: Duke University Press.

Taylor, Anne C. 1993. "Remembering to Forget: Identity, Mourning and Memory among the Jivaro." Man (n.s.) 28: 653-678.

Vilaça, Aparecida. 2000. "Relations between Funerary Cannibalism and Warfare Cannibalism: The Question of Predation.” Ethnos 65, no. 1: 83-106.

Vilaça, Aparecida. 2005. "Chronically Unstable Bodies: Reflections on Amazonian Corporalities." Journal of the Royal Anthropological Institute 11, no. 3: 445-464.

Vilaça, Aparecida, and Robin M. Wright, eds. 2009. Native Christians: Modes and Effects of Christianity among Indigenous Peoples of the Americas. London: Ashgate. Viveiros de Castro, Eduardo. 2004. "The Forest of Mirrors: A Few Notes on the Ontology of Amazonian Spirits." http://amazone.wikia.com/wiki/The_Forest_of_Mirrors (accessed 13/2/2014).

Wetaru, Tëmeta, and Cees Koelewijn. 2003. Tëmeta Inponopïhpë Panpira [Tëmeta’s Testament]. Katwijk: Van den Berg. 